\title{
New Video Class Added to the 2021 International Metallographic Contest (IMC)
}

\author{
Deadline for Entry Receipt: September 3, 2021
}

(c) ASM International 2021

The International Metallographic Contest (IMC), an annual contest cosponsored by the International Metallographic Society (IMS) and ASM International to advance the science of microstructural analysis, will take place on September 12 as part of IMAT 2021. The conference is scheduled for St. Louis, September 13-16. Six different classes of competition-including a new video class — cover all fields of optical and electron microscopy:

Class 1: Light Microscopy-All Materials

Class 2: Electron Microscopy-All Materials

Class 3: Student Entries-All Materials (Undergraduate Students Only)

Class 4: Artistic Microscopy (Color)_All Materials

Class 5: Artistic Microscopy (Black and White)_All Materials

NEW-Class 6: Video Entry-Topic of Choice (Undergraduate Students Only)

Class 6 is a pilot class for 2021, aimed at engaging undergraduate students who may be unable or have limited access to the laboratory due to COVID-19 restrictions. This class is a video format on a topic of choice related to a specific material, family of material, a specific component, or a process for materials.

Images used in entries for Classes 1, 2, or 3 may not be utilized in Class 6.

The full list of International Metallographic Contest requirements may be accessed online at https://www. asminternational.org/web/ims/membership/imc/requirements

\section{Class 6 Specific Requirements are as follows:}

17. Focus to be a specific material, family of material, a specific component, or a process for materials.
18. Video Length-4-5 min long

19. Entries should include at least 3 of the 5 following components:

a. Interview(s) with industry professional(s) regarding topic of choice.

b. Interview(s) with current graduate student(s) or professor(s) working with the chosen material(s) or process regarding current innovations and/or research.

c. Unique uses for material(s) or process chosen.

d. Challenges in the industry regarding the chosen material(s) or process.

e. How the material(s) or process chosen is a good choice for our environment or sustainability.

20. Signed release forms are required for each individual interviewed or shown in the video

21. Maximum file size-To be determined

22. Video format-To be determined

For a complete description of the rules, tips for creating a winning entry, and judging guidelines, visit the IMS website at https://www.asminternational.org/web/ims/membership/ imc.

For further information, e-mail: Ellen Rabenberg (IMC Chair) at: ellen.m.rabenberg@ nasa.gov.

Publisher's Note Springer Nature remains neutral with regard to jurisdictional claims in published maps and institutional affiliations. 